\title{
Moro med statistikk
}

\begin{abstract}
I Tidsskriftet har det nylig vært flere artikler der man ved hjelp av statistikk har søkt å påvise og motbevise forskjellige fenomeners årstidsvariasjoner/ukedagsvariasjoner/tallverdivariasjoner. Dr. Brochmann drøfter i Tidsskriftet nr. 12/1930 om det er sammenheng mellom årstid og tuberkulosesykdom. Han finner at helbredelsesraten henger sammen med når på året man ble syk, dessuten at det er klare kjønnsforskjeller mennene blir syke om sommeren og kvinnene om vinteren. Hans hypotese er at mennene får sykdommen etter påkjenningene under vinterfisket, for kvinnenes del kan det være fristende å tenke på «klædedrakten om vinteren» (Tidsskr Nor Lægeforen 1930; 50: 674-8). Tuberkelbakterien Mycobacterium tuberculosis ble oppdaget av Robert Koch allerede i 1882.
\end{abstract}

Vensmoen sanatorium - Chef: overlæge Schram.

\section{Lungetuberkulosen og årstiden.}

\section{Av S.W. Brochmann.}

I «Tidsskrift for Den norske lægeforening», nr. 9, 1928 har assistentlæge ved Vensmoen sanatorium J . F. B r a t t skrevet en artikkel som bl. a. viser at plevrittenes opståen er fortrinsvis knyttet til månedene april og desember, de tidsperioder da patientene gjennemsnittlig har lav vektøkning.

Etter opfordring av overlæge Schram har jeg gjennemgått sanatoriets journaler fra 1924 til 1928 (begge år inkl.) for å se om det gjør sig en lignende lovmessighet gjeldende når det gjelder lungetuberkulosens opståen.

Nu er det selvsagt av en anamnese lettere å slutte sig til en plevritts enn til en lungetuberkuloses opståen. Ved den første har man jo «stinget» å holde sig til. Men jeg har søkt efter beste evne å bedømme lungetuberkulosens opståen efter de kjente subjektive symptomer slapphet, dårlig matlyst, nattesved, hoste o. 1. I adskillige tilfelle har en hæmoptyse vært første symptom. Hvor der har vært en tydelig kontinuitet i symptomene mellem en plevritt og den senere konstaterte lungetuberkulose, er plevrittens begynnelse antatt som lungetuberkulosens begynnelse. Hvor man ikke har hatt så sikre oplysninger at nogen sannsynlig slutning om sykdommens begynnelse har kunnet trekkes, der er tilfellet ikke tatt med i statistikken.

I alt er der fra sanatoriet i nevnte tidsrum - 5 år - utskrevet 1874 patienter. I 1664 tilfelle er oplysningene så gode at man har lagt dem til grunn for statistikken. Av disse 1664 patienter er de 787 menn og 877 kvinner, altså med et rundt tall 10 pct. mer kvinner enn menn. De 1664 patienter fordeler sig hvad hjemsted angår således: Fra Finnmark fylke 155, fra Troms fylke 341 og fra Nordlands fylke 1168. Blant de 1168 fra Nordlands fylke er der en forsvinnende liten del fra Trøndelagsfylkene.

Lungetuberkulosens begynnelse faller hos disse 1664 patienter på følgende måneder: (...) Desember, april, mars, mai, juni, januar, februar, november, juli og september. Vi finner et maksimum i månedene mars til juni (våren og forsommeren), derefter et tydelig fall fra juli utover høsten til og med november og så atter en rask stigning i desember. Månedene april og desember står som i B ratts undersøkelser med de høieste tall. Grafisk fremstillet tar det sig ut som ovenfor. B r a t t s tall er her angitt med prikkede, mine tall med kontinuerlige linjer.

Hvis man vil se om der er nogen forskjell på menn og kvinner i denne henseende, må man ta hensyn til at der i det samlede materiale var ca. 10 pct. mere kvinner enn menn. I parentes har jeg derfor satt de tall som fremkommer når man til antall menn legger 10 pct. Det ser da ut til at lungetuberkulosen begynner oftere hos menn i månedene mai, juni og august, og oftere hos kvinner i månedene desember, januar, februar og mars. Med andre ord, at sykdommen begynner oftere hos menn om sommeren og oftere hos kvinner om vinteren. Det er jo selvsagt små tall man har å fare med her, så det tør være meget tvilsomt om man kan slutte noget av dem. Det vilde jo ellers være fristende iallfall å tenke på kvinnene og klædedrakten om vinteren.

I Nord-Norge er jo mannfolkene optatt med Lofot- og Finnmarksfiske fra januar til juni, og det er vel ikke tvilsomt at de sliter meget ondt i denne tid både hvad ernæring, kulde og spesielt slett hygiene angår. At så virkningen av dette skulde komme i sommermånedene i form av en stigning av tuberkulosetallene kan vel tenkes.

Av samtlige 1664 patienter var ved innkomsten 849 bacillære og 815 abacillære, altså omtrent like mange av hver gruppe. Jeg har undersøkt om de bacillære resp. abacillære tilfelle av sykdommen tilhører nogen bestemt årstid. Men det kan jeg ikke finne at de gjør. (...) Der er dernest undersøkt om kurresultatet har nogen forbindelse med i hvilken måned sykdommen begynner. (...) Under begrepet «godt resultat» er regnet følgende kurresultater: «Symptomfri», «Betydelig bedret» og «Bedret». Til begrepet «Dårlig resultat» er regnet: «Uforandret», «Forverret», «Ikke egnet til sanatoriebehandling» og «Død». Vi ser da av tallene at forholdet mellem «dårlig» og «godt» resultat for hele beleggets vedkommende er omtrent som 1:3 (424:1231). Det samme forhold finner man nogenlunde nøiaktig i alle måneder undtagen i april, hvor forholdet er omtrent $1: 2$, i juli hvor forholdet er $1: 7$ og i september hvor forholdet er 1:4.

Hvis man har lov til å trekke nogen slutning av dette, så blir det den, at kurresultatet er dårligst hos de patienter hos hvem sykdommen begynner i april (om våren) og best hvor sykdommen begynner i juli (om sommeren). Enten er altså sykdommen mere malign hos dem som får den om våren eller organismens motstandskraft er mindre i denne årstid, som oppe i Nord-Norge på så mange måter fortjener navnet «vårknipa».

Min ærbødige takk til overlæge $\mathrm{S} \mathrm{c} \mathrm{h} \mathrm{r} \mathrm{a} \mathrm{m} \mathrm{for} \mathrm{tilskyndelse} \mathrm{til} \mathrm{og}$ interesse for denne lille statistikk. 